TITLE:

\title{
Multi-annual variation in the diet composition and frugivory of the Japanese marten (Martes melampus) in western Tokyo, central Japan
}

\author{
AUTHOR(S): \\ Tsuji, Yamato; Yasumoto, Yui; Takatsuki, Seiki
}

\section{CITATION:}

Tsuji, Yamato ... [et al]. Multi-annual variation in the diet composition and frugivory of the Japanese marten (Martes melampus) in western Tokyo, central Japan. Acta Theriologica 2014, 59(3): 479-483

ISSUE DATE:

2014-07

URL:

http://hdl.handle.net/2433/199598

\section{RIGHT:}

The final publication is available at Springer via http://dx.doi.org/10.1007/s13364-0140181-1.; この論文は著者最終稿です。内容が印刷版と異なることがありますので、引用 の際には出版社版をご確認ご利用ください。This is the Accepted Author Manuscript. Please cite only the published version. 
1 Multi-annual variation in the diet composition and frugivory of the Japanese marten (Martes

2 melampus) in western Tokyo, central Japan

3

4 Yamato Tsuji $^{1^{*}}$, Yui Yasumoto ${ }^{2}$, and Seiki Takatsuki ${ }^{2}$

$5 \quad{ }^{1}$ Primate Research Institute, Kyoto University, Aichi 484-8506 Japan

$6 \quad{ }^{2}$ School of Veterinary Medicine, Azabu University, Kanagawa 229-8501 Japan

$7 \quad$ Running headline: multi-annual variation in diet of Japanese martens

8 *to whom correspondence should be addressed: ytsuji1002@gmail.com, Tel/Fax: +81-568-63-0539

9

10 Abstract To examine multi-annual variations in the food habits of the Japanese marten (Martes

11 melampus), we analyzed the composition of marten feces in the Bonbori Forest Path in western Tokyo,

12 central Japan in two time periods a decade apart (1997-1998 and 2007-2008). The staple foods of

13 martens in both periods were fruits/seeds and animal materials (mainly insects and mammals). The

14 martens fed frequently on fruits/seeds and insects throughout the year in both periods, but the

15 consumption of mammals, birds, and arthropods/other animals showed seasonal variations. The

16 composition of fruits/seeds and the frequency of occurrence for each fruit-bearing species differed

17 between the two periods. These results suggest that both the foraging strategy and role of martens as a

18 seed dispersal agent changes yearly, presumably according to multi-annual variation in the availability of 
Tsuji et al. 2

19 prey animals and/or fruits. We emphasize the importance of multi-annual studies both on food habits and

20 to monitor food availability in the temperate region where the food environment changes among seasons as well as years.

Keywords Dietary composition $\bullet$ Frequency of occurrence $\bullet$ Martes melampus $\bullet$ Multi-annual $\bullet$ Seed

dispersal • Yearly variation

\section{Introduction}

Food habit analysis is a basic and important subject in studies on wildlife ecology. The food environment

varies both temporally and spatially in accordance with variations in food availability (Herrera et al.

1998; McShea 2000). In temperate regions, marked seasonal changes in plant phenology limit the fruiting

period of frugivores (Hanya et al. 2013). Such variations in plant availability often affect the population

size of prey animals, such as small rodents and sedentary birds, which in turn affect the food environments of omnivorous mammals (Helldin 1999; McShea 2000). As a result, both frugivorous and carnivorous mammals in temperate regions seem to change their food habits according to environmental conditions (O'Donoghue et al. 1998; Naves et al. 2006; Tsuji et al. 2006; Koike 2010), which implies that multi-annual information on the food habits of animals is needed to fully understand temporal variation in their feeding ecology. 
Tsuji et al. 3

Mustelids (family Mustelidae) are small- to medium-sized mesopredators that have a wide

distribution in the Northern Hemisphere (Buskirk et al. 1994). Martens, as generalist predators, switch to alternative prey when their principal foods are not readily available. Several multi-annual studies have shown that martens fed on rodents (voles and mice) during years when their availability was high, while the rodent availability was low (Pulliainen and Ollinmäki 1996; Ben-David et al. 1997). These examples imply that information about marten food habits based on short-term studies can lead to erroneous conclusions about their foraging strategies. Mustelids also feed on fruits (Rosalino and Santos-Reis 2009), and therefore potentially disperse intact seeds that pass through their digestive tracts (endozoochory; Wilson 1993; Otani 2002). Thus, multi-annual variation in their food habits can also affect their roles as seed dispersal agents. Despite numerous studies on the food habits of mustelids, few have attempted multi-annual studies on variations in diet composition and its implications. In this study, we tried to address multi-annual variation in the food habits of wild Japanese martens (Martes melampus), an endemic mustelid species in Japan. We especially focused on multi-annual variation in their frugivory. Although several studies have examined the food habits of Japanese martens (Yamagishi 1990; Tatara and Doi 1994; Arai et al. 2003), no study except Arai et al. (2003) documented multi-annual variation. In western Tokyo, the food habits of Japanese marten were previously studied by 
Tsuji et al. 4

multi-annual variation in diets by conducting a follow-up study in 2007-2008 (Period 2) and comparing

the results between these two periods.

\section{Materials and methods}

59 Our study was conducted at the Bonbori Forest Path $\left(36^{\circ} \mathrm{N}, 139^{\circ}\right.$ E) between Hachioji City and Akiruno

60 City, approximately $50 \mathrm{~km}$ west of the central part of Tokyo. The path is about $10 \mathrm{~km}$ long and about $5 \mathrm{~m}$

61 wide, and it is almost entirely asphalt-paved (Tsuji et al. 2011a). Mean annual precipitation and

temperature at Hachioji, the nearest weather station to the study site, during Period 1 were $2358 \mathrm{~mm}$ and

$14.8^{\circ} \mathrm{C}$, respectively, while in Period 2, they were $2074 \mathrm{~mm}$ and $14.6^{\circ} \mathrm{C}$, respectively (Japan

64 Meteorological Agency, http://www.jma.go.jp/jma/index.html). The area is mostly covered with forest

vegetation dominated by deciduous broad-leaved secondary forests on slopes as well as planted

coniferous forests of Cryptomeria japonica and Chamaecyparis obtusa in valleys (Nakamura et al. 2001;

Tsuji et al. 2011a).

We surveyed the forest path at least once a month from July 2007 to July 2008 (23 surveys in total),

69 and collected marten feces along/on it. When we found feces in one large pile, we treated it as one sample

if the color was the same or as independent samples if the color differed. We could easily distinguish

marten feces from that of sympatric mammals, such as Japanese macaques (Macaca fuscata) and red fox

(Vulpes vulpes) by its shape. We could also distinguish marten feces from that of sympatric mustelids, 
Tsuji et al. 5

73 Japanese weasels (Mustela itatsi), by its size (mean \pm SD width: $10.1 \pm 1.5 \mathrm{~mm}$ for martens and $6.5 \pm 1.1$

$74 \mathrm{~mm}$ for weasels; Tsuji et al. 2011b). When we collected feces, we removed stones and leaves that were

75 present on the surface.

77 sieve were identified under a microscope. Based on Nakamura et al. (2001), we classified the contents

into the following eight categories: mammals (including rodents and insectivores), birds,

reptiles/amphibians, insects, arthropods/other animals, fruits/seeds, other plant parts (including leaves,

stems, and roots), and others/unidentified items. To examine multi-annual variation in the contribution of

81 fruits, fruits/seeds were sorted to the level of species or genus. Fruits/seeds identification followed

82 Nakayama et al. (2000) and our own references. The percent frequency of occurrence in feces $(\% F O=$ number of fecal samples containing a specific food item/total number of fecal samples) was used to show seasonal and year-round food habits, as well as multi-annual variation. difference was obtained, we conducted post-hoc Bonferroni tests to address when the martens fed on the 
Tsuji et al. 6

91 Bonferroni tests in which we adjusted the significance levels $(\alpha)$ to 0.013 (for 4 seasons) and 0.017 (for 3

92 seasons) to avoid type I error. Data analyses in this study were performed using the statistical software R

$93 \quad 2.15 .1$.

\section{$95 \quad$ Results}

96 During Period 2, we collected 381 fecal samples, among which we analyzed 257 samples $(N=33$ in

97 spring, 20 in summer, 26 in fall, and 178 in winter). In total, 594 identifiable food items were found in the

98257 fecal samples, which corresponded to an average of 2.32 food categories per fecal sample $(\mathrm{SD}=$

990.83 , range: $1-5$ ). Fruits/seeds (annual \%FO: 94.9), mammals (annual \%FO: 69.6), insects (annual \%FO:

100 51.0), and other plant parts (annual \%FO: 61.5) were the staple food items during Period 2 (Table 1).

101 Birds, reptiles/amphibians, arthropods/other animals, and fungi were supplementary sources, whose annual $\% F O$ s were less than $5 \%$.

As to seasonal change, the $\% F O$ of mammals in Period 2 was significantly higher in spring and summer than winter $(p<0.017)$. The $\% F O$ of birds in Period 2 was significantly higher in spring than

105 winter $(p<0.013)$. The $\% F O$ of arthropods/other animals in Period 1 was significantly higher in spring

106 than other seasons $(p<0.013)$, while $\% F O$ of arthropods/other animals in Period 2 was significantly

107 higher in summer than winter $(p<0.013)$ (Table 1).

108 Significant effects of study period on $\% F O$ were detected for mammals in the annual mean $\left(\chi^{2}=\right.$ 
$1094.7, d f=1, p=0.031)$, for birds in winter $\left(\chi^{2}=11.8, d f=1, p<0.001\right)$, reptiles and amphibians in the

110 annual mean $\left(\chi^{2}=3.9, d f=1, p=0.049\right)$, arthropods/other animals in the annual mean $\left(\chi^{2}=11.1, d f=1, p\right.$

$111<0.001$ ), and other plant parts in each season (spring: $\chi^{2}=16.3, d f=1, p<0.001$; summer: $\chi^{2}=20.0, d f=$ 1, $p<0.001$; fall: $\chi^{2}=11.4, d f=1, p<0.001$; winter: $\chi^{2}=9.3, d f=1, p=0.002$; the annual mean: $\chi^{2}=$

$11365.1, d f=1, p<0.001)$. However, no significant difference in $\% F O$ was observed for insects and

114 fruits/seeds among the study periods ( $p>0.05$ for each; Table 1$)$.

116 fruits appeared in feces during only one period (Table 1): in spring, Rubus spp. and Aspidistra elatior

117 fruits appeared only in Period 1, while Actinidia arguta, Stachyurus praecox, Morus bombycis, Hovenia

118 dulcis, Pyrus pyrifolia, Celtis sinensis, Aphananthe aspera, and Physalis alkekengi appeared only in

119 Period 2; in summer, Rubus spp., A. arguta, and Broussonetia kazinoki appeared only in Period 1, while

120 M. bombycis appeared only in Period 2; in fall, Rubus sp., H. dulcis, and Cinnamomum camphora

121 appeared only in Period 1, while C. sinensis, Viburnum dilatatum, Cocculus orbiculatus, and Sorbus $\mathrm{sp}$. appeared only in Period 2; in winter, Cardiospermum halicacabum, Mollugo verticillata, and Prunus sp. appeared only in Period 1, while S. praecox, H. dulcis, P. pyrifolia, C. sinensis, Prunus jamasakura, Actinidia polygama, and Vitex spp. appeared only in Period 2 (Table 1). 
Tsuji et al. 8

127 Rubus spp. $\left(\chi^{2}=4.7, d f=1, p=0.030\right)$ and Diospyros kaki $\left(\chi^{2}=51.2, d f=1, p<0.001\right)$ were

128 significantly higher in Period 1 , while the $\% F O$ of $A$. $\operatorname{arguta}\left(\chi^{2}=10.1, d f=1, p=0.002\right)$ was higher in

129 Period 2. On an annual basis, the \%FOs of Rubus spp. $\left(\chi^{2}=14.9, d f=1, p<0.001\right), D$. kaki $\left(\chi^{2}=11.2, d f\right.$

$130=1, p=0.001)$, Akebia quinata $\left(\chi^{2}=14.1, d f=1, p<0.001\right)$, and P. jamasakura $\left(\chi^{2}=15.7, d f=1, p<\right.$

$1310.001)$ were significantly higher in Period 1 , while those of A. arguta $\left(\chi^{2}=45.5, d f=1, p<0.001\right)$ and $S$. $\operatorname{praecox}\left(\chi^{2}=8.5, d f=1, p=0.003\right)$ were significantly higher in Period 2 (Table 1$)$.

\section{Discussion}

Japanese martens in the Bonbori Forest Path fed mainly on animal materials and fruits during both study

periods. Their omnivorous diets were similar to what has been reported at other sites (Yamagishi 1990;

137 Tatara and Doi 1994; Arai et al. 2003). In terms of seasonal changes in food habits, the martens fed frequently on fruits/seeds and insects throughout the year in both periods, while other categories, like mammals, showed seasonal variation.

141 mammals, reptiles/amphibians, and arthropods/other animals were higher, while those of some berry

142 species were lower in Period 1 than in Period 2. Since climatic conditions were similar between the two

143 periods (see Materials and methods), the results strongly suggest three possibilities: fruit production

144 varied annually, prey animal abundance varied annually, or both fruit production and prey animal 
Tsuji et al. 9

145 abundance varied annually. The availability of prey animals (Saito et al. 1998, 2007) and fruit production

146 (Komiyama et al. 1991; Suzuki et al. 2005) are known to vary annually in Japan. Thus, the martens at our

147 study site seem to adjust their dependence on animal materials in accordance with the availability of prey

148 animals and/or fruits, as do other mustelids (Buskirk et al. 1994; Pulliainen and Ollinmäki 1996; Zhou et

149 al. 2011; Caryl et al. 2012). In this study we could not quantify the food availability, and our

150 interpretation of the multi-yearly variation in the dietary composition is speculative. Collecting such

151 information would be useful to investigate how dietary preferences change with availability of their staple foods.

We also found considerable variation in fruit occupation in the fecal composition between the two

study periods. A similar phenomenon was noted by Otani (2002) when studying martens in northern

Japan: he found differences in fruit composition among samples during a 2-year study; e.g., seeds of

156 Taxus cuspidata var. nana and Prunus nipponica were only found in feces in 1 year. These results can be

157 attributed to yearly variation in fruit production. In our study, for example, the availability of $A$. arguta and S. praecox from fall to the next spring should have been greater in Period 2, while the availability of

Rubus sp. in all seasons except for fall, D. kaki and A. quinata in fall, and Prunus japonica in summer agents would also vary annually according to fruit availability. 
Tsuji et al. 10

163 leaves that were attached to the surface of fecal samples at collection, detected leaves were likely to be

164 food-originated. Folivory by Japanese martens has been reported at other study sites (e.g., Shiratsuki et al.

165 1973; Yamagishi 1990). Whether folivory is a "side effect" of capturing insects on leaves or a separate

166 feeding strategy of the martens is not clear. The amount of leaves in feces, however, was very low

167 (Yamagishi 1990), and the relative importance of leaves for martens seems lower than that of fruits and

168 animal matter.

We demonstrated that multi-annual studies are required to fully understand temporal variation in

marten diet. Furthermore, monitoring the availability of plant and prey animals is necessary to explain

multi-annual variation in the foraging behaviors performed by martens (e.g., Pulliainen and Ollinmäki would be useful to meta-analyses investigating large-scale drivers of prey availability and diet.

176 Acknowledgments This study was supported in part by the Cooperative Research Fund of the Wildlife

177 Research Center, Kyoto University, and Grants-in-Aid from the Department of Academy and Technology of Japan (No. 20255006). We would like to thank handling editor and two anonymous reviewers for their constructive comments on an earlier version of our manuscript. 
Tsuji et al. 11

\section{$181 \quad$ References}

182 Arai S, Adachi T, Kawahara Y, Yoshida K (2003) Food habit of Japanese marten (Martes melampus) at

183 Kuju Highland in Kyushu, Japan. Mamm Sci 43:19-28 [in Japanese with English summary]

184 Ben-David M, Flynn RW, Schell DM (1997) Annual and seasonal changes in diets of martens: evidence

185 from stable isotope analysis. Oecologia 111:280-291

186 Buskirk SE, Harestad AS, Raphael MG, Powell RA (1994) Martens, sables and fishers: biology and

187 conservation. Cornell University Press, Ithaca

188 Caryl FM, Raynor R, Quine CP, Park KJ (2012) The seasonal diet of British pine marten determined from genetically identified scats. J Zool Lond 288: 252-259

190 Hanya G, Tsuji Y, Grueter CC (2013) Fruiting and flushing phenology in Asian tropical and temperate forests: implications for primate ecology. Primates 54:101-110

Helldin JO (1999) Diet, body condition, and reproduction of Eurasian pine martens Martes martes during

194 Herrera CM, Jordano P, Guitian J, Traveset A (1998) Annual variability in seed production by woody

195 plants and the masting concept: reassessment of principles and relationship to pollination and seed dispersal. Am Nat 152:576-594

197 Koike S (2010) Long-term trends in food habits of Asiatic black bears in the Misaka Mountains on the

198 Pacific coast of central Japan. Mamm Biol 75:17-28 
199 Komiyama A, Wada K, Kuga H (1991) Annual fluctuation of seed-fall amounts in the basin of Yokoyu

200 River, Shiga Heights. Bull Gifu Univ Exp Forest 56:166-174 [in Japanese with English summary]

201 McShea WJ (2000) The influence of acorn crops on annual variation in rodent and bird populations.

203 Nakamura T, Kanzaki N, Maruyama N (2001) Seasonal changes in food habits of Japanese martens in

204 Hinode-cho and Akiruno-shi, Tokyo. Wildl Cons Japan 6:15-24 [in Japanese with English summary]

205 Nakayama S, Inokuchi M, Minamitani T (2000) Encyclopedia of plant seeds of Japan. Tohoku University

$206 \quad$ Press, Sendai [in Japanese]

207 Naves J, Fernández-Gil A, Rodorĭguez C, Delibes M (2006) Brown bear food habits at the border of its range: a long-term study. J Mamm 87:899-908

209 O'Donoghue M, Boutin S, Krebs CJ, Zuleta G, Murray DL, Hofer EJ (1998) Functional responses of

$210 \quad$ coyotes and lynx to the snowshoe hare cycle. Ecology 79:1193-1208

211 Otani T (2002) Seed dispersal by Japanese marten Martes melampus in the subalpine shrubland of northern Japan. Ecol Res 17:29-38

213 Pulliainen E, Ollinmäki P (1996) A long-term study of winter food niche of the pine marten Martes

$214 \quad$ martes in northern boreal Finland. Acta Theriol 41:337-352

215 Rosalino LM, Santos-Reis M (2009) Fruit consumption by carnivores in Mediterranean Europe. Mamm $216 \quad$ Rev 39:67-78 
Tsuji et al. 13

217 Saitoh T, Stenseth NC, Bjørnstad ON (1998) The population dynamics of the vole Clethrionomys

218 rufocanus in Hokkaido, Japan. Res Pop Ecol 40:61-76

219 Saitoh T, Osawa J, Takanishi T, Hayakashi S, Ohmori M, Morita T, Uemura S, Vik JO, Stenseth NC,

220 Maekawa K (2007) Effects of acorn masting on population dynamics of three forest-dwelling rodent species in Hokkaido, Japan. Pop Ecol 49:249-256

Shiratsuki N, Asahi M, Yoshida H (1973) Food habit of Japanese marten Martes melampus, with consideration on the home range. Bull Mukogawa Women Univ 20/21:45-56 [in Japanese with English summary]

Suzuki W, Osumi K, Masaki T (2005) Mast seeding and its spatial scale in Fagus crenata in northern Japan. For Ecol Manage 205:105-116

Tatara M, Doi T (1994) Comparative analyses on food habits of Japanese marten, Siberian weasel and leopard cat in the Tsushima islands, Japan. Ecol Res 9:99-107

Tsuji Y, Fujita S, Sugiura H, Saito C, Takatsuki S (2006) Long-term variation in fruiting and the food habits of wild Japanese macaques on Kinkazan Island, northern Japan. Am J Primatol 68:1068-1080

Tsuji Y, Tatewaki T, Kanda E (2011a) Endozoochorous seed dispersal by sympatric mustelids, Martes melampus and Mustela itatsi, in western Tokyo, central Japan. Mamm Biol 76:628-633

Tsuji Y, Uesugi T, Shiraishi T, Miura S, Yamamoto Y, Kanda E (2011b) Faecal size criteria to discriminate Japanese marten (Martes melampus) and Japanese weasel (Mustela itatsi). J Zoo and Aquarium 
Tsuji et al. 14

$235 \quad 52: 8-15$ [in Japanese with English summary]

236 Wilson MF (1993) Mammals as seed-dispersal mutualists in North America. Oikos 67:159-176

237 Yamagishi M (1990) Seasonal food habits of the Japanese marten. Bull Exp Forest Univ Tokyo 83:9-18

$238 \quad$ [in Japanese with English summary]

239 Zhou YB, Newman C, Xu WT, Buesching CD, Zalewski A, Kaneko Y, Macdonald DW, Xie ZQ (2011)

240 Biogeographical variation in the diet of Holarctic martens (genus Martes, Mammalia: Carnivora:

241 Mustelidae): adaptive foraging in generalists J Biogeogr 38:137-147

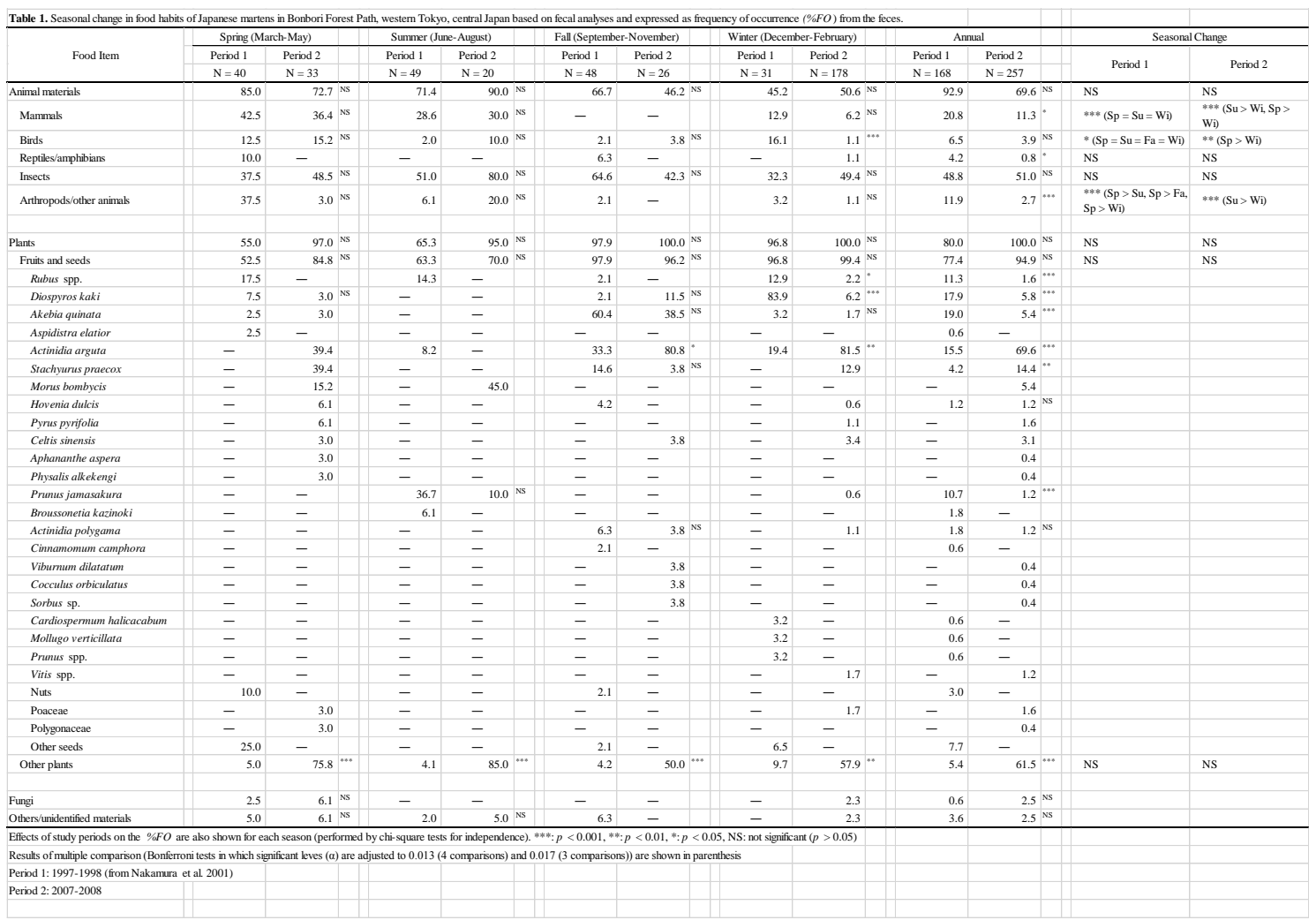

244 The English in this document has been checked by at least two professional editors,

245 both native speakers of English. For a certificate, please see: 
1

2

3

4

5

6

7

8

10

11

12

13

14

15

16

17

18

19

20

21

22

23

24

25

26

27

28

29

30

31

32

33

34

35

36

37

38

39

40

41

42

43

44

45

46

47

48

49

50

51

52

53

54

55

56

57

58

59

60

61

62

63

64

65

Tsuji et al. 15

246 http://www.textcheck.com/certificate/kd7Qi1 